Rev. Bras. Saúde Prod. Anim., Salvador, v.17, n.2, p.186-194 abr./jun., 2016 http://www.rbspa.ufba.br ISSN 15199940

\title{
Increasing levels of concentrate digestibility, performance and ingestive behavior in lambs
}

\author{
Teores de concentrado sobre a digestibilidade, desempenho e comportamento ingestivo \\ de cordeiros
}

PARENTE, Henrique Nunes ${ }^{1 *}$; PARENTE, Michelle de Oliveira Maia ${ }^{1}$; GOMES, Ruan Mourão da Silva ${ }^{1}$; SODRÉ, Wesclley de Jesus dos Santos ${ }^{1}$; MOREIRA FILHO, Miguel Arcanjo $^{1}$; RODRIGUES, Rosane Cláudia ${ }^{1}$; SANTOS, Viviany Lúcia Fernandes dos ${ }^{2}$; ARAÚJO, Jocélio dos Santos ${ }^{1}$

\footnotetext{
${ }^{1}$ Universidade Federal do Maranhão, Centro de Ciências Agrárias e Ambientais, Chapadinha, Maranhão, Brasil.

${ }^{2}$ Universidade Federal do Rio Grande do Norte, Unidade Acadêmica Especializada em Ciências Agrárias, Macaíba, Rio Grande do Norte, Brasil.

*Endereço para correspondência: hnparente@hotmail.com
}

\section{SUMMARY}

The objectives of this research were to determine the effects increasing levels of concentrate on nutrients digestibility, performance, economic viability of diets and ingestive behavior of lambs. Fifteen crossbred lambs were used in a randomized complete block design according to initial body weight and age. Lambs were penned individually during 55 days, being 10 days for adaptation of diets and 45 days for data collection. The treatments consisted in three isonitrogenous diets with increasing levels of concentrate: 40, 60, or $80 \%$, in dry matter basis. No effect $(\mathrm{P}>0.05)$ were observed on dry matter intake, crude protein intake, crude protein digestibility and neutral detergent fiber digestibility, whereas the dry matter digestibility was lower $(\mathrm{P}<0.01)$ for lambs fed diets with $40 \%$ of concentrate. The addition of $80 \%$ concentrate decreased $(\mathrm{P}<0.05)$ neutral detergent fiber intake, however this treatment provided higher average daily gain, followed by 60 and $40 \%$ of concentrate. In relation to feeding behavior, the animals fed $80 \%$ concentrate spent more time with feeding $(\mathrm{P}<0.05)$ compared to the other treatments. It is concluded that supplementation of concentrate between 60 to $80 \%$ improves dry matter digestibility and performance of crossbred lambs without relevant affect dry matter intake and ingestive behavior. A diet with $80 \%$ concentrate provides positive gross margin of profit.

Keywords: average daily gain, high grain diet, intake, nutritive value

\section{RESUMO}

Os objetivos com este experimento foram avaliar a digestibilidade dos nutrientes, o desempenho produtivo, viabilidade econômica das dietas, assim como o comportamento ingestivo de cordeiros terminados em confinamento recebendo dietas com a inclusão de três teores de concentrado. Quinze cordeiros machos nãocastrados, sem padrão racial definido (SPRD) foram distribuídos em blocos casualizados de acordo com a idade e peso inicial. Os animais foram confinados por um período de 55 dias, sendo dez dias de adaptação e 45 para coleta dos dados. Os tratamentos consistiram em três dietas isonitrogenadas com diferentes teores de concentrado: $40 \% ; 60 \%$ e $80 \%$, com base na matéria seca. Os consumos de matéria seca (MS) e proteína bruta (PB), assim como a digestibilidade da $\mathrm{PB}$ e fibra em detergente neutro (FDN) não foram alterados $(\mathrm{P}>0,05) \mathrm{com}$ a inclusão de concentrado na dieta. Os animais alimentados com $40 \%$ de concentrado apresentaram menor $(\mathrm{P}<0,01)$ digestibilidade da MS. A adição de $80 \%$ de concentrado na dieta reduziu $(\mathrm{P}<0,01)$ o consumo de $\mathrm{FDN}$, porém proporcionou maior $(\mathrm{P}<0,01)$ ganho de peso médio diário dos animais, seguido pelos tratamentos com $60 \%$ e $40 \%$ de concentrado. Em relação ao comportamento ingestivo, os animais alimentados com $80 \%$ de concentrado apresentaram maior tempo gasto com alimentação $(\mathrm{P}<0,05)$. Dietas com altos teores de concentrado $(60-80 \%)$ aumentam a digestibilidade da matéria seca e proporciona 
Rev. Bras. Saúde Prod. Anim., Salvador, v.17, n.2, p.186-194 abr./jun., 2016 http://www.rbspa.ufba.br ISSN 15199940

melhor desempenho dos animais, sem relevantes alterações no comportamento ingestivo. A dieta com $80 \%$ de concentrado proporciona margem bruta de lucro positiva.

Palavras-chave: consumo, dieta de alto grão, ganho de peso, valor nutritivo

\section{INTRODUCTION}

The Northeast region has the largest sheep herd in Brazil with $55.5 \%$ of the national total (IBGE, 2012). Sheep breeding is one of the main economic activities of the northeast, mainly for meat production, which satisfies much of the demand for animal protein for the local population. However, the production system in this region is characterized as extensive, showing low stocking rate of native pastures, low meat and low reproductive efficiency, resulting in a low economic performance to farmers

The growing demand for sheep meat, registered over the last years, propelled the increase in the lamb production for slaughter, creating a necessity of improvement in the exploration techniques (OLIVEIRA et al., 2009). Quality and quantity of feed are the major factors in increasing ruminant productivity under tropical conditions. Increase in energy density in diets by providing larger quantities of concentrate feeds may improve feed efficiency and animal performance contributing to higher overall efficiency in utilization of dietary energy for body weight gain.

The feeding is one of the most important parts in animal production, and, associated with the confinement system, it is possible to maintain the same nutritional level during all the fattening period, different from pastures, which may present nutritional difference because of oscillations in its quality. So, the advantages of this system include fast and efficient growth, when compared to animals raised in pastures for the same period of time (BARROS et al., 2009).

Increase in energy density in diets by providing larger quantities of concentrate may improve feed efficiency and animal performance (MISSIO et al., 2010a). Therefore, in this work, the aim was to evaluate the effect of increasing levels of concentrate digestibility, on performance and ingestive behavior in lambs.

\section{MATERIAL AND METHODS}

This study was conducted from May to July 2014 at the Small Ruminant Sector, Centro de Ciências Agrárias e Ambientais, Universidade Federal do Maranhão (CCAA/UFMA). Fifteen uncastrated male crossbred lambs (initial BW of $18.2 \pm 3.2 \mathrm{~kg}$ and $150 \mathrm{~d}$ old) were housed indoor and individually allotted in pens $(1.3 \mathrm{~m} \mathrm{x} 3.5 \mathrm{~m})$ with a concrete floor, feed bunk, mineral box, and waterer. All lambs were dewormed with $1 \mathrm{~mL}$ of $1 \%$ moxidectin (Fort Dodge Animal Health).

The experimental design consisted of a randomized complete block, with 3 treatments and 5 blocks per treatment. The blocks were defined according to the weight and age of the animals at the beginning of the experiment. The experiment lasted 55 days (10 days for animal's adaptation with diet and 45 days for data collection). The treatments were defined by increasing levels of concentrate: $\quad 40, \quad 60, \quad$ or $\quad 80 \%$ corresponding to the experimental diets C40, C60 and C80, respectively. The experimental diets were formulated according to National Research Council (NRC, 2007) for average daily gain of $200 \mathrm{~g}$. The percentual of ingredients and chemical composition of the diets is shown in Table 1. 
Rev. Bras. Saúde Prod. Anim., Salvador, v.17, n.2, p.186-194 abr./jun., 2016 http://www.rbspa.ufba.br ISSN 15199940

Table 1. Ingredients and chemical composition of experimental diets, $\%$ dry matter

\begin{tabular}{|c|c|c|c|}
\hline \multirow{2}{*}{ Ingredients } & \multicolumn{3}{|c|}{ Proportion of concentrate } \\
\hline & 40 & 60 & 80 \\
\hline Tifton- 85 hay & 60.00 & 40.00 & 20.00 \\
\hline Corn meal & 10.96 & 29.44 & 51.41 \\
\hline Soybean meal & 11.45 & 12.95 & 10.97 \\
\hline Wheat bran & 10.33 & 10.46 & 10.35 \\
\hline Flour starch of babaçu & 5.04 & 5.05 & 5.04 \\
\hline Urea & 0.89 & 0.89 & 0.89 \\
\hline Mineral supplement ${ }^{1}$ & 1.33 & 1.21 & 1.34 \\
\hline \multicolumn{4}{|l|}{ Chemical composition } \\
\hline Dry matter & 91.48 & 91.48 & 91.49 \\
\hline Crude protein & 16.76 & 17.12 & 16.05 \\
\hline Neutral detergente fiber & 56.70 & 43.89 & 30.72 \\
\hline Metabolizable energy, Mcal/Kg DM ${ }^{2}$ & 2.23 & 2.51 & 2.78 \\
\hline
\end{tabular}

Corn was ground using a grinder and mixed with soybean meal, flour starch of babassu, wheat bran, urea and mineral premix.Tifton- 85 hay was also coarsely chopped to reduce the animal diet selection and feed waste. The concentrate and the Tifton-85 hay were weighed separately on an electric scale with an accuracy of $5 \mathrm{~g}$, mixed, and offered once a daily in the form of total mixed ration once a day. All animals had ad libitum access to feed and fresh water. Feed offered and refused were recorded daily to adjust feed offered for $10 \%$ refusal and to determine the animal DMI later. Both were sampled weekly and frozen at $-20^{\circ} \mathrm{C}$ for later analysis. Animals were weighed after a $14 \mathrm{~h}$ fast on days 0 and 45 of the experimental period to determine the average daily gain (ADG) and feed efficiency ( $g$ of $\mathrm{BW}$ gain $/ \mathrm{kg}$ of feed).

The ingestive behavior was evaluated on the 23th day of the experiment. The scan sampling method was used to record the time spent on eating, rumination and idling. This was done in five-minute intervals starting at 7 a.m. by trained observers during 24 straight hours, according Johnson \& Combs (1991). Artificial lighting was used during nighttime observations.

The feed and rumination efficiencies, expressed as g DM/hour were obtained by dividing the average daily intake of DM by the total time spent eating and/or ruminating in 24 hours, respectively (AZEVEDO et al., 2013).

The total time in minutes per day for each animal spent in each activity was calculated by multiplying the total number of observations by five. The activities of ruminating and feeding were expressed in minutes/day and minutes/g of DM intake, expressed by the ratio between the intake of daily time and rumination and the amount of the nutrient daily intake.

The water intake also was determined in feedlot period. During 05 days in the last week of experimental period, the quantity of supply water and orts were registered in period of 24 hours. During the observation period of water intake, a bucket to the same specifications stocked with8 liters was used, placed in 
the center of the house, being weighed and refilled every 24 hours to obtain the estimated values of evaporation.

At the end of the feedlot, for digestibility trial, a harness equipped with a bag was used in lambs for fecal collection, in order to prevent the urine from mixing with feces. During four days in the collection period, at $7 \mathrm{~h} 00$ in the morning, the orts were weighed to obtain the dry matter intake (DMI) per animal and total amount of feces generated in 24 hours. Samples of feed, orts and feces $(100 \mathrm{~g} / \mathrm{kg}$ of the total) were collected during four days, forming composite samples per animal, and preserved at $-20^{\circ} \mathrm{C}$ for later analyses.

All samples were thawed and dried in a forced-ventilation oven $\left(55^{\circ} \mathrm{C}\right)$ for 72 hours and ground with a Wiley-typemill to pass through a $1 \mathrm{~mm}$ screen. The DM content of feed offered, orts and feces was determined after oven-drying the samples at $105^{\circ} \mathrm{C}$ for $24 \mathrm{~h}$ according to the method of the Association of Official Analytical Chemists (AOAC, 1990). The total nitrogen (N) concentration also was determined according AOAC (1990) (method 968.06). Crude protein (CP) was obtained by multiplying the total $\mathrm{N}$ content by 6.25 . Neutral detergent fiber (NDF) was determined according to Van Soest et al. (1991), using heatstable alpha-amylase and sodium sulfite with an Ankom 200 Fiber Analyzer.

The digestibility of DM, CP and NDF was calculated according to adapted formula of Coelho da Silva \& Leão (1979): $\operatorname{Dig}(\%)=\left[\left(\mathrm{N}_{\mathrm{I}}-\mathrm{N}_{\mathrm{F}}\right) \div \mathrm{N}_{\mathrm{I}}\right] \mathrm{x}$ 100, that: $\mathrm{N}_{\mathrm{I}}=$ nutrient intake and $\mathrm{N}_{\mathrm{F}}=$ nutrient in feces.

The determination of the economic viability was based on the calculation of the gross profit margin (GM), described by Cartaxo et al. (2008), which are considered the values for the confinement period, average dry matter intake, weight gain and diet costs, using the following equation: $\mathrm{GM}=$ [TWG $\mathrm{x}$ LW (R\$)] - [PC x DMI x CD] where: $\mathrm{GM}=$ gross profit margin ( $\mathrm{R} \$$ /animal); $\mathrm{TWG}=$ weight gain during the confinement; LW $(\mathrm{R} \$)=$ price per $\mathrm{kg}$ live animal practiced in the region; $\mathrm{PC}$ $=$ confinement period; DMI $=$ average dry matter intake; $C D=$ cost of diets.

A completely randomized design was used to analyze the performance, digestibility and ingestive behavior. The blocks were defined according to the weight and age of the animals at the beginning of the experiment. The Shapiro-Wilk normality test was used to check the homogeneity of variances. The PROC MIXED procedure of Statistical Analysis System (SAS, 1999) was used according to the model: $\mathrm{Y}=\mu$ $+\mathrm{Bi}+\mathrm{Dj}+\mathrm{Eij}$, where $=$ the overall mean; $\mathrm{Bi}=$ the random effect of block ( $\mathrm{i}$ $=1-5) ; \mathrm{Dj}=$ the fixed effect of $\operatorname{diet}(\mathrm{j}=$ $1-3)$; and $\mathrm{Eij}=$ the residual error.

The means were obtained using the LSMEANS command. Orthogonal polynomials for treatment responses were determined by linear and quadratic responses to increasing levels of concentrate. Effects were declared significant at $\mathrm{P}<0.05$.

\section{RESULTS AND DISCUSSION}

No effect $(\mathrm{P}>0.05)$ were observed on dry matter intake (DMI) and crude protein intake (CPI) of lambs fed increasing levels of concentrate (Table 2).

Ribeiro et al. (2009) and Oliveira et al. (2009) evaluated different levels of concentrate for calves and Santa Inês lambs, respectively, and reported a decrease in DMI and CPI for animals fed lower level of concentrate. 
Rev. Bras. Saúde Prod. Anim., Salvador, v.17, n.2, p.186-194 abr./jun., 2016 http://www.rbspa.ufba.br ISSN 15199940

Tabela 2. Intake and digestibility of nutrients and performance of lambs fed increasing levels of concentrate

\begin{tabular}{|c|c|c|c|c|c|}
\hline \multirow[b]{2}{*}{ Item } & \multicolumn{3}{|c|}{ Proportion of concentrate } & \multirow{2}{*}{$\mathrm{CV}^{1}$} & \multirow{2}{*}{$\mathrm{P}^{2}$} \\
\hline & $40 \%$ & $60 \%$ & $80 \%$ & & \\
\hline \multicolumn{6}{|l|}{ Dry matter } \\
\hline Intake, $\mathrm{g} / \mathrm{d}$ & 757.71 & 887.47 & 858.48 & 23.43 & 0.58 \\
\hline Digestibility, $\%^{3}$ & 80.18 & 87.53 & 88.16 & 5.48 & $<0.01$ \\
\hline \multicolumn{6}{|l|}{ Crude protein } \\
\hline Intake, $\mathrm{g} / \mathrm{d}$ & 144.34 & 167.83 & 146.02 & 14.17 & 0.49 \\
\hline Digestibility, \% & 91.03 & 92.21 & 91.56 & 1.45 & 0.55 \\
\hline \multicolumn{6}{|l|}{ Neutral detergente fiber } \\
\hline Intake, $g / d^{4}$ & 392.28 & 336.94 & 244.94 & 26.75 & 0.01 \\
\hline Digestibility, \% & 72.12 & 78.63 & 73.81 & 7.48 & 0.16 \\
\hline \multicolumn{6}{|l|}{ Performance } \\
\hline Average daily gain, $g / d^{5}$ & 60.10 & 126.05 & 232.56 & 36.81 & $<0.01$ \\
\hline Feed efficiency ${ }^{6}$ & 0.08 & 0.14 & 0.23 & 39.63 & $<0.01$ \\
\hline
\end{tabular}

In this study, although DMI did not alter, the animals fed diets with 60 and $80 \%$ of concentrate showed 17.3and 13.3\%, respectively, higher DMI when compared to animalsfed $40 \%$ concentrate. Regarding CPI, the lack of effect is related to result obtained for DMI, considering that the diets were isonitrogenous.

Usually, in high-forage diets, the decrease of DMI is limited by physiological mechanism. This physical limitation can occurred, because of accumulation of fiber in the rumen that is associated to cell wall constituent and higher colonization and degradation times, approximated to 6 and $72 \mathrm{~h}$, respectively, otherwise to high concentrate diets with levels that have lower colonization times and higher degradability in a shorter interval of time, around 3 and $48 \mathrm{~h}$, respectively (NRC, 2001).

The DM digestibility increased linearly $(\mathrm{P}<0.01)$ with increasing levels of concentrate, while $\mathrm{CP}$ digestibility was unaffected $(\mathrm{P}>0.05)$ by diets (Table 2$)$. The response for DM digestibility is associated to the increase of NDF from forage inclusion in the diets up to the inclusion level of $40 \%$ of concentrate. According Jung \& Allen (1995), the often low digestibility and high concentration of cell walls in forages limit energy availability to animals fed high-forage diets.

Incorporation of concentrate in ruminant diets is intended to optimize the efficiency of feed utilization for growth and production. However, according Tripathi et al. (2006), concentrate supplementation may reduce digestibility in forage containing diets by cattle and sheep that is related to a decrease in ruminal $\mathrm{pH}$, a preference by rumen microbes for readily fermentable carbohydrates. However, the extent of effect of concentrate on digestion depends on the nature and proportion of the concentrate as well as the quality of the forage species. Therefore, high quality forage is less susceptible to negative associated effects when concentrate is incorporated in the diet than are low quality forages.

In this study, probably higher concentrate intake and low hay intake with high quality possibly synchronized 
Rev. Bras. Saúde Prod. Anim., Salvador, v.17, n.2, p.186-194 abr./jun., 2016 http://www.rbspa.ufba.br ISSN 15199940

better nutrient availability for optimum rumen fermentation and microbial growth, which in turn improved DM digestibility. This result is agreement with Tripathi et al. (2006) that evaluated effects of free choice tree leaves feeding with restricted or ad libitum concentrate supplementation of weaner lambs and also related higher DM digestibility with increasing concentrate feeding.

The Neutral Detergent Fiber intake (NDFI) decreased linearly $(\mathrm{P}<0.05)$ with increasing levels of concentrate, while NDF digestibility was unaffected $(\mathrm{P}>0.05)$ (Table 2). The results obtained with NDFI was associated to proportion of NDF from forage inclusion in the diets up to the inclusion level of $60 \%$ of hay that increased NDF content of diets. Regarding the NDF digestibility, the lack of effect is probably due to the increase in the amount of concentrate, because the diets with higher levels of concentrate (C60 and C80) despite lower NDF had a higher digestibility rate compared to the $\mathrm{C} 40$ diet. According Jung \& Allen (1995), fiber is an analytical product having nutritional characteristics that describe those forage components that have low solubility in specific solvent systems and are relatively less digestible than starch.

The average daily gain (ADG) increased linearly $(\mathrm{P}<0.01)$ with increasing concentrate levels (Table 2). Although no difference was found in DMI, this result might be attributed to the different levels of metabolizable energy in diets (Table 1).

The feed efficiency increased linearly $(\mathrm{P}<0.05)$, that is explained by ADG results. The results of this study are consistent with the statement by Sahu et al. (2013) that evaluated increasing levels of concentrate in diets of pregnant goats. The results of this study also agreement with the statement by Carvalho et al. (2007) that evaluated performance of lambs fed different concentrate: roughage ratio and reported increase in ADG for higher levels of concentrate in diets. However, Moletta et al. (2014) reported that increasing levels of concentrate $(0.8 ; 1.1$. and $1.4 \%$ of BW) had no effect on bulls and steers performance that is justified by lower protein and total nutrient digestible (TND) intake.

There was no effect $(\mathrm{P}>0.05)$ on water intake (Table 3). According Vieira et al. (2008), the main way for the animal to obtain water is by direct ingestion, this behavior can be altered due to the water content in food. In this study, the diets had a similar moisture content (Table 1), which explained this result.

Table 3. Water intake and ingestive behavior of lambs fed increasing levels of concentrate

\begin{tabular}{lccccc}
\hline \multirow{2}{*}{ Item } & \multicolumn{3}{c}{ Proportion of concentrate } & \multirow{2}{*}{$\mathrm{CV}^{1}$} & \multirow{2}{*}{$\mathrm{P}^{2}$} \\
\cline { 2 - 4 } & $40 \%$ & $60 \%$ & $80 \%$ & & \\
\hline Water intake, g/day & 1788.20 & 2538.20 & 2585.80 & 37.60 & 0.44 \\
Water intake from food, g/day & 71.00 & 81.40 & 80.00 & 23.26 & 0.65 \\
Eating, min/d & 307.00 & 300.00 & 240.00 & 16.69 & 0.03 \\
Rumination, min/d & 495.00 & 462.00 & 391.00 & 18.31 & 0.12 \\
Iddle, min/d & 505.00 & 493.00 & 589.00 & 19.25 & 0.29 \\
Other activities, min/d & 133.00 & 185.00 & 220.00 & 35.43 & 0.08 \\
Eating efficiency, g DM/h & 149.33 & 182.29 & 226.13 & 39.37 & 0.27 \\
Rumination efficiency, g DM/h & 92.40 & 116.45 & 132.43 & 25.31 & 0.08 \\
\hline${ }^{1}$ Coeficient of variation ${ }^{2}$ P-probability value ${ }^{3}{ }^{3} \mathrm{Y}=382,83-1,675 \mathrm{X} ; \mathrm{R}_{2}=0.3609$. & &
\end{tabular}


Regarding ingestive behavior (Table 3), the eating time decreased linearly $(\mathrm{P}<0.05)$ with increasing level of concentrate, due the fact that C80 treatment was rapidly ingested by lambs, although the DMI did not change (Table 2). Missio et al. (2010b) also observed less time of intake when evaluated the ingestive behavior of feedlot finished young bulls fed different concentrate levels in the diet and attributed this results to differences in the NDF concentrations among the experimental diets. Furthermore, the higher NDF concentration from C40 diet, probably, increased the animal selectivity .
The levels of concentrate did not affect $(\mathrm{P}>0.05)$ the eating efficiency $(\mathrm{g} \mathrm{DM} / \mathrm{h})$, rumination efficiency $(\mathrm{g} D M / h)$, time spent in other activities, time spent in idle and time spent in rumination.

It was expected that time spent in rumination was higher in diets with high forage, although did not observed difference in time spent in rumination, , the animals fed C80 spent approximately 21 and $18 \%$ less time with this activity when compared to $\mathrm{C} 40$ and C60 diets, respectively, that is related to less NDF from fiber in diet (Table 4).

Table 4. Gross profit margin obtained with increasin levels of concentreate in the diet of finishing lambs

\begin{tabular}{lccc}
\hline \multirow{2}{*}{ Item } & \multicolumn{3}{c}{ Proportion of concentrate } \\
\cline { 2 - 4 } & 40 & 60 & 80 \\
\hline Observation & 5.00 & 5.00 & 5.00 \\
Cost of diets (kg of MS) & 1.40 & 1.29 & 1.15 \\
Toatal gain (kg) & 2.70 & 5.67 & 10.44 \\
$\mathrm{R} \$ \mathrm{~kg}$ of live weigh & 9.00 & 9.00 & 9.00 \\
Dry matter intake/animal $(\mathrm{kg})$ & 0.757 & 0.887 & 0.858 \\
Total intake, $\mathrm{kg} /$ day/treatment & 3.79 & 4.44 & 4.29 \\
Dairy cost with feed (R\$/day) & 5.31 & 5.75 & 4.93 \\
Confinement (days) & 45.00 & 45.00 & 45.00 \\
Gross profit margin/animal (R\$) & -23.35 & -0.46 & 49.55 \\
\hline
\end{tabular}

The levels of 60 and $80 \%$ concentrate feeding optimized DM digestibility and performance of crossbred lambs without relevant affect DM and water intake and ingestive behavior. According to Maeda et al. (2012), non-fiber carbohydrates have a total apparent digestibility coefficient near of $90 \%$ and fiber carbohydrates between 30 and 50\%, which reflects increased in DM digestibility with lower levels of fiber carbohydrates.

At the end of the experiment, it was observed that only the diets with $80 \%$ of concentrate has proven to be economically viable, by providing a gross profit margin of $\mathrm{R} \$ 49.55$ (Table 4). The low profit expected in treatment with lower concentrate contents occurred in part to the high cost of Tifton hay used (US \$ 1.44 per $\mathrm{kg} \backslash \mathrm{DM}$ ) as roughage, while corn ingredient used on a large scale in diets with higher levels of concentrate presented lower price $(0.75$ per $\mathrm{kg} \backslash \mathrm{DM})$. According this fact, it is important for producers to intensify the system of sheep production in feedlots with high levels of concentrate in the diet to enhance the nutritional benefits and achieve the maximum weight gain in a shorter interval of time. 
Rev. Bras. Saúde Prod. Anim., Salvador, v.17, n.2, p.186-194 abr./jun., 2016 http://www.rbspa.ufba.br ISSN 15199940

\section{ACKNOWLEDGEMENTS}

The authors are grateful to FAPEMA (The State of Maranhão Research and Cientific Development Foundation) for the financially support. Appreciation is extended to undergraduate students for assistance and animal care during this study.

\section{REFERENCES}

ASSOCIATION OF OFFICIAL ANALYTICAL CHEMISTS - AOAC. Official methods of analysis of $\mathrm{AOAC}$ international. $19^{\text {th }}$.ed. Gaithersburg, MD, USA: Association of Analytical Communities, 2012.

AZEVEDO, R.A.; RUFINO, L.M.A.; SANTOS, A.C.R.; RIBEIRO JÚNIOR, C.S.; RODRIGUEZ, N.M.; GERASEEV, L.C. Comportamento ingestivo de cordeiros alimentados com torta de macaúba. Arquivo Brasileiro de Medicina Veterinária e Zootecnia, v.65, n.2, p.490-496, 2013.

BARROS, C.S.; MONTEIRO, A.L.G.; POLI, C.H.E.C.; DITTRICH, J.R.; CANZIANI, J.R.F.; FERNANDES, M.A.M. Rentabilidade da produção de ovinos de corte em pastagem e em confinamento. Revista Brasileira de Zootecnia, v.38, p.2270-2279, 2009.

CANNAS, A.; TEDESCHI, L.O.; FOX, D.G.; PELL, A.N.; VAN SOEST, P.J. A mechanistic model for predicting the nutrient requirements and feed biological values for sheep. Journal of Animal Science, v.82, n.1, p.149-169, 2004.

CARTAXO, F.Q.; SOUSA, W.H.; CÉZAR, M.F.; GONZAGA NETO, S.; CUNHA, M.G.G. Efeitos do genótipo e da condição corporal sobre o desempenho de cordeiros terminados em confinamento. Revista Brasileira de Zootecnia, v.37, n.8, p.1483-1489, 2008.
CARVALHO, S.; BROCHIER, M.A.; PIVATO, J.; TEIXEIRA, R.C.;

KIELING, R. Desempenho e avaliação econômica da alimentação de cordeiros confinados com dietas contendo diferentes relações volumoso:concentrado. Ciência Rural, v.37, n.5, p.1411-1417, 2007.

INSTITUTO BRASILEIRO DE GEOGRAFIA E ESTATÍSTICA IBGE. Produção da pecuária municipal, v.40, 2012. Disponível em: $<$ http://ftp.ibge.gov.br/Producao_Pecuaria /Producao_da_Pecuaria_Municipal/2012/ ppm2012.pdf.>. Acesso em: 25 fev. 2015

JOHNSON, T.R.; COMBS, D.K. Effects of prepartum diet, inert rumen bulk, and dietary polythylene glicol on dry matter intake of lactating dairy cows. Journal of Dairy Science, v.74, n.3, p.933-944, 1991.

JUNG, H.G.; ALLEN, M.S.

Characteristics of plant cell walls affecting intake and digestibility of forages by ruminants. Journal of Animal Science, v.73, n.9, p.2774-2790, 1995.

MAEDA, E.M.; ZEOULA, L.M.; JOBIM, C.C.; CECATO, U.; RIGOLON, L.P.; KAZAMA, R.; JACOBI, G.; CARVALHO, A.F.G. Intake, digestibility, rumen characteristics and microbial protein synthesis efficiency in bovine and bubaline fed sugar cane silage with additives. Revista Brasileira de Zootecnia, v.41, n.3, p.707-716, 2012.

MISSIO, R.L.; BRONDANI, I.L.; ALVES FILHO, D.C.; RESTLE, J.; ARBOITTE, M.Z.; SEGABINAZZI, L.R. Características da carcaça e da carne de tourinhos terminados em confinamento, recebendo diferentes níveis de concentrado na dieta. Revista Brasileira de Zootecnia, v.39, n.7, p.1610-1617, 2010. 
Rev. Bras. Saúde Prod. Anim., Salvador, v.17, n.2, p.186-194 abr./jun., 2016 http://www.rbspa.ufba.br ISSN 15199940

MISSIO, R.L.; BRONDANI, I.L.; ALVES FILHO, D.C.; SILVEIRA, M.F.; FREITAS, L.S.; RESTLE, J.

Comportamento ingestivo de tourinhos terminados em confinamento, alimentados com diferentes níveis de concentrado na dieta. Revista Brasileira de Zootecnia, v.39, p.1571-1578, 2010.

MOLETTA, J.L.; TORRECILHAS, J.A.; ORNAGHI, M.G.; PASSETTI, R.A.C.; EIRAS, C.E.; PRADO, I.N. Feedlot performance of bulls and steers fed on three levels of concentrate in the diets.

Acta Scientarum. Animal Science, v.36, n.3, p.323-328, 2014.

NATIONAL RESEARCH COUNCIL NRC. Nutrient requirements of dairy cattle. $7^{\text {th }}$ rev.ed. Washington, D.C.: National Academy Press, 2001. 381p.

NATIONAL RESEARCH COUNCIL NRC. Nutrient requirements of small ruminants: sheep, goats, cervids, and new world camelids. $7^{\text {th }}$.ed. Washington: National Academy Press, 2007. 362p.

OLIVEIRA, R.P.; PEREZ, J.R.O.; MUNIZ, J.A.; EVANGELISTA, A.R.; SOUZA, J.C.; BARCELOS. A.F. Effect off concentrate: voluminous ratio on theon the performance of Santa Inês lambs. Ciência e Agrotecnologia, v.33, n.6, p.1637-1642, 2009.

RIBEIRO, M.D.; PEREIRA, J.K.; BETTERO, V.P.; QUEIROZ, A.C.; COSTA, M.G.; LEONEL, F.P. Níveis de concentrado na dieta de bezerros. Revista Brasileira de Zootecnia, v.38, n.6, p.1133-1141, 2009.

SAHU, S.; BABU, L.K.; KARNA, D.K.; BEHERA, K.; KANUNGO, S.; KASWAN, S.; BISWAS, P.; PATRA, J.K. Effect of different level of concentrate supplementation on the periparturient growth performance of Ganjam goat in extensive system. Vet World, v.6, n.7, p.428-432, 2013.
SAMPAIO, I.B.M. Estatística aplicada à experimentação animal. 3.ed. Belo Horizonte: FEPMVZ, 2007. 264p.

SILVA, J.F.C.; LEÃO, M.I.

Fundamentos de nutrição dos ruminantes, Piracicaba: Livroceres, 1979. 380p.

TRIPATHI, M.K.; KARIM, S.A.; CHATURVEDI, O.H.; SINGH, V.K. Effect of ad libitum tree leaves feeding with varying levels of concentrate on intake, microbial protein yield and growth of lambs. Livestock Research for Rural Development, v.18, n.12, p. 327-338, 2006.

VAN SOEST, P.J.; ROBERTSON, J.B.; LEWIS, B.A. Methods for extraction fiber: neutral detergent fiber and nonstarch polysaccharides in relation animal nutrition. Journal of Dairy Science, v.74, n.10, p.3583-3597, 1991.

VIEIRA, E.L.; BATISTA, A.M.V.; GUIM, A; CARVALHO, F.F.; NASCIMENTO, A.C.; ARAÚJO, R.F.S.; MUSTAFA, A.F. Effects of hay inclusion on intake, in vivo nutriente utilization and ruminal fermentation of goats fed spineless cactus (Opuntiaficus-indica Mill) based diets. Animal Feed Science and Technology, v.141, n.3-4, p.199-208, 2008.

Data de recebimento: 09/07/2015

Data de aprovação: 20/05/2016 